\title{
When Mary tells Joseph: A play based on Matthew 1:18-19
}

Author:

Robin Gallaher Branch ${ }^{1,2}$

Affiliations:

${ }^{1}$ Faculty of Theology, North-

West University, South Africa

${ }^{2}$ Department of Bible and

Theology, Victory University,

Memphis, United States

\section{Correspondence to:}

Robin Gallaher Branch

Email:

rgbranch@victory.edu

\section{Postal Address:}

Victory University, 255 North Highland, Memphis, TN 38111; USA; 901-320-9700 x 1091

Dates:

Received: 08 June 2011

Accepted: 17 Jan. 2012

Published: 30 July 2013

How to cite this article: Branch, R.G., 2013, 'When Mary tells Joseph: A play based on Matthew 1:18-19', In die Skriflig/In Luce Verbi 47(1), Art. \#92, 12 pages. http://dx.doi.org/10.4102/ ids.v47i1.92

Note:

Dedicated to Thabiso Katiba, JC Potgieter and Esmari Linde, three fine actors who played the Narrator, Joseph, and Mary respectively in a production of the play in February 2013 in Potchefstroom, South Africa.

\section{Copyright:}

(C) 2013. The Authors.

Licensee: AOSIS

OpenJournals. This work

is licensed under the

Creative Commons

Attribution License.
Read online:

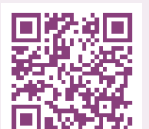

Scan this QR code with your smart phone or mobile device to read online.
This play looks at a summary in Matthew 1:18-19. ${ }^{1}$ The summary discloses that Joseph learns of Mary's pregnancy and chooses to divorce her. The play, based on this summary, investigates how he may have learned of her pregnancy, that is, from Mary herself. ${ }^{2}$ The play combines scholarship and the standard literary features of a drama-character, conflict, plot, setting, point of view, tone and dialogue. ${ }^{3}$ It includes material from Luke 1, Deuteronomy 22:21-29 and Numbers 30:6-8. The play encourages and engages the imagination of the cast and the audience. ${ }^{4}$

Toe Maria vir Josef vertel het: 'n toneelstuk gebaseer op Matteus 1:18-19. Hierdie toneelstuk handel oor die gedeelte in Matteus 1:18-19, waar Josef uitvind van Maria se swangerskap en besluit om van haar te skei. Die toneelstuk ondersoek die manier waarop hy van haar swangerskap te hore kom, naamlik van Maria self. In die drama word vakkundigheid gekombineer met die tipiese literêre elemente van 'n karakterspel, naamlik konflik, intrige, uitgangspunte, stemming en dialoog. Dele uit Lukas 1, Deuteronomium 22:21-29 en Numeri 30:6-8 word ook ingesluit. Die verbeelding en betrokkenheid van die rolspelers en die gehoor word deur die toneelstuk aangewakker.

\section{The characters}

Announcer: He or she is a modern person in modern dress.

Mary: $\quad$ A young woman betrothed to Joseph; she is young, pretty and graceful.

Joseph: A carpenter in Nazareth; he is bearded and handsome and a bit older than Mary.

Time: $\quad$ Daytime. About 4 BC

Place: $\quad$ The carpentry shop and home of Joseph in Nazareth of Galilee, a Roman Province.

Set: $\quad$ A carpenter's shop with wooden tools and wooden implements like a yoke for oxen and a shepherd's staff. Wooden sawhorses with lumber on them are upstage left and upstage right and are part of Joseph's home and shop. Simple wooden tools are spread on them. Two wooden benches adorn centre stage. There is ample room to move around the wooden furniture on the stage. ${ }^{5}$ An imaginary door is downstage left. A black stage curtain marks

1.To date, there have been four performances of this play. However, reading a play also gives satisfaction. DiYanni (2008:900) expresses this as, 'How do we imaginatively reconstruct a play in our minds? Essentially, we translate the script we read into a mental performance that we imagine.' We read Matthew 1:18-19 frequently in churches, especially at Christmas. Long (2001:44) views a service of worship in which a text is read as a play, a play performed in a kind of community theatre with God as the audience. The worshippers are the actors 'and the words and actions of worship form the script' for the various parts of the actors (Long ibid:44).

2.Forde (1990:15) observes 'It is a mistake to believe that there are two different sorts of art: Christian art and everybody else's art. Art is not different in this respect from, say, cooking. Good bread made by a pagan is just as nourishing as good bread made by a Christian The worth and validity of a piece of art stand separate from the beliefs of its creator. And that is true even when those beliefs are embodied in it. Art is not a matter of content but of form.'

3.Edyvean (1970:18-19) distinguishes religious drama and its elements from Christian drama. Christian drama combines these elements: 1. The idea that human beings are, in some way, responsible. The drama may investigate freedoms or limits, but it addresses the concept that people are responsible for their actions and are whole people.

2.It explores Christian concepts like forgiveness, repentance, atonement, judgment, fellowship, confession, trials, trust and faith 3. Christian drama emphasises redemption and hope, no matter how dire the circumstances.

4. Love is human love directed toward others and directed upward toward God. This is in contrast to a worldly idea of love that dotes on self-love. 5. There is symbolism.

6. Tesus Christ is central. We see the life of Christ in the characters in some way.
. Then symbolism.

According to Edyvean's definition, this play, based on Matthew 1:18-19, is Christian drama. One way to look at a text and the theology it contains is to view it as a sacred experience, specifically as a range of sacred experiences 'accessible to the contemporary heart and mind' (Wells 2004:35-36). Wells (ibid:37) advises against denying the narrative and overemphasising a 'propositional truth'. In other words, drama can express a text.

4.Brown (2008:177-178), a strong advocate of combining imagination and Christianity, thinks that imagination and faithful exegesis help explain difficult miracles or difficult moral lessons, as in the case of Elijah on Mount Carmel and his slaughter of the false prophets (1 exp 18). For Kgs 18). For example, this play invites the audience to imagine a carpenter's shop and what Mary and Joseph look like. A reader does these things quite naturally whe reading a text. Somo allows passionate, in scholarship, book knowledge and street smarts. However, Pitzele (ibid:13) sees the Bible as a living myth. I see it and its characters as real. We agree, however, that the biblical text is 'relevant, disturbing, and still capable of taking our breath away' (see Pitzele ibid:13). Bibliodrama begins with the ability to read the biblical text creatively (Pitzele ibid:26). Although starting with commentaries, the interaction moves on to the stage where 'the text is given a voice and answers me back', Pitzele (ibid:28) writes.

5.The stage is minimal. The blocking, the movements of the actors on the stage (see DiYanni 2008:929), weaves in and around Joseph's two workstations and the wooden chairs in the centre of the stage. 
the horizontal upstage boundary of the single room stone house.

Costumes: $\quad$ Mary and Joseph wear sandals and old, loose, long clothes. Mary wears a graceful head covering. Joseph's hands are those of a working man.

(Mary is upstage left with her back to the audience. Joseph is stage right with his back to the audience. He quietly works with his tools at the sawhorses. The Announcer enters carrying a Bible. The Announcer greets the audience warmly. ${ }^{6}$ )

\section{Introduction}

Announcer: The Holy Scriptures contain many silences. Often a writer squeezes together events and summarises them. ${ }^{7}$ The scriptures in both testaments are known for their brevity, their conciseness. This play investigates one such silence in the Gospel of Matthew. ${ }^{8}$ The silence involves when Mary tells Joseph she is pregnant with the Son of God. ${ }^{9}$

This short play relies on supplemental information about the birth of Jesus the Messiah from the Gospel of Luke. ${ }^{10}$ Listen to the summary from the Gospel of Matthew. ${ }^{11}$

6.1 am a writer of a drama based on the biblical text. Therefore, I followed these guidelines:

1. What do I want to cover in the play? (See Pitzele 1998:117.)

2. What opportunities do I see for providing sound commentary on the text?
3. Who are the characters in the scene and what are their normal emotions?

3. Who are the characters in the scene and what are their normal emotions?
4. How do I build accurately upon the parts of the play, taken from a summary in scripture, to reflect other sections of the scripture?

5. Where is God in the drama? (See Pitzele ibid:221-224; Branch 2009:181-184.) [Author has to provide the correct page number as it differs from the reference list]

7.Anderson (2006:9-10) believes that there are two ways to approach a study of the Bible. The first is an academic study in the classroom. The second is what he calls an attempt to stand within the Bible and to look out at the world through the window of biblical faith' (Anderson's italics). Anderson (ibid:12-13) continues to write that the Bible presents historical drama. Like any great drama, biblical drama portrays a unity, because it moves from a beginning to an end and from one creation to new one. Although the Bible has many different authors, many different historica new one. Although the Bible has many different authors, many different historical situations and many kinds of theological expressions, it combines this great variet into dynamic movement, something 'similar to the plot of a drama, that binds the whole together, Anderson (ibid:13) maintains. However, that 'God appears in the (n) stands behind the scenes prompting and directing the drama, but God also enters onto
the stage of history as the Chief Actor - the protagonist', Anderson (ibid:13) says.

8.Whilst I was writing this play, I remembered the insights and definitions that Quash (2005:3-4) gives: 'Drama displays human actions and temporal events in specific contexts. Theodramatics concerns itself with human actions (people), temporal events (time), and their specific contexts (places) in relation to God's purpose (Quash's italics). According to Lostracco and Wilkerson (2008:1), the central idea of a story reveals the author's point of view on some aspect of life'. My academic work has been largely on obscure portions of Scripture and often on silent and unnamed women I investigate silences in the biblical text instead of reading quickly over them. This play presents one such time of reflection and pause. The setting supports them. This play present the place in the home or workshop of Joseph (see Lostracco \& Wilkerson ibid:32).

9.The conversation between Mary and Joseph must have provoked Joseph's anger, because he decides to divorce Mary. In deciding to write a play about this conversation, I realised that drama has advantages over succinct prose in the following ways (see Clark, Brubaker \& Zuck 1986:545-546):

1.A story often becomes real and alive with enactment.

2.A drama on the stage conveys honest emotions and feelings. A reader may miss these feelings with just a casual read.

3. A drama provides a teaching venue and a learning venue quite different from a classroom.

4. A drama promotes friendships on levels different from those in a classroom. 5. Becoming actors in a play enables people to think outside themselves.

6. Taking part in a drama allows an actor, via imagination, to gain insights into the thinking and actions of another person.

10.The accounts of Matthew and Luke differ in that Matthew emphasises Joseph 'whose dreams and actions stitch the narrative together', whilst Luke's gospe 'centers on Mary and parallels the births of Jesus and John the Baptist' (Strauss 2007:220). However, both gospels focus on themes of fulfilment and promise, on Jesus as the descendant of David, the one born to be king and on the comin of Jesus as the fulfilment of the hopes of the Jews (Strauss ibid:220). Brown (2008:184) believes that 'unusual stimuli', like a drama that portrays a text (2008:184) bol portrays a text, "can

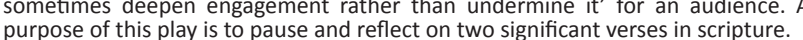

11.This play refutes the charge that the birth of Jesus in the way it came about is myth or imagination on the part of Matthew, because Luke records similar details in different account. Furthermore, the tone of both Matthew and Luke is different
Announcer: [The Announcer opens the Bible.] Matthew 1:18-19:13 'This is how the birth of Jesus Christ came about: His mother Mary was pledged to be married to Joseph, but before they came together, she was found to be with child through the Holy Spirit. Because Joseph her husband was a righteous man and did not want to expose her to public disgrace, he had in mind to divorce her quietly. ${ }^{12}$ [The Announcer closes the Bible.]

Announcer: The scene is home of Joseph of Nazareth. [Joseph quietly starts sawing.] It is a small stone house. ${ }^{13}$ The door is over there. [The Announcer gestures stage left.] $\mathrm{He}$ is a carpenter. The time is around $4 \mathrm{BC}$. Herod is king in Judea. The Romans occupy the land. [Mary turns and walks toward the imaginary door, downstage left, and starts knocking. The Announcer turns and smiles.] Ah, someone is at the door. [The Announcer walks stage left and opens the door. If the Announcer is a man, he bows to Mary. If the Announcer is a woman, she nods her head. Mary enters; she wears a headdress and/ or cowl gracefully over her head. The Announcer leaves and returns either to a seat in the audience or goes off stage. The imaginary door remains open.]

\section{Mary's return from Elizabeth}

Mary:

[Mary enters Joseph's shop.] Shalom, Joseph. ${ }^{14}$ May I see you for a moment? ${ }^{15}$ [Joseph stops, turns, puts down his tools, smiles. He rises to greet Mary.]

Joseph: $\quad$ Peace to you as well, Mary. ${ }^{16}$ It is wonderful to see you. ${ }^{17}$ [They are a little awkward with each other.

(Footnote 11 continues ...)

from the tone of pagan stories that recount when the gods had intercourse with from the tone of pagan stories that recount when the gods had intercourse with many times. Childers (1998:9) comments that, whilst preachers and the theatre many times. Childers (1998:9) comments that, whilst preachers and the theatre
share much in common, 'the vast, fertile country where preachers and actors share much in common, 'the vast, fertile country where preachers and actors
may tip back their chairs in the sun and enjoy what the other knows is largely may tip back their chairs in the sun and enjoy what the other knows is largely
unexplored'. She (Childers ibid:11) believes that theatre is the 'closest cousin' to preaching. Preaching is a theological event (Childers ibid:21) and, therefore by its very nature, drama.

12.The word quietly puzzles scholars, because a divorce had to have witnesses and Mary's pregnancy eventually and quickly would become well known. Furthermore, people would assume that her divorce was because of her adultery and the evidence of her adultery was the child (see Brown 1979:128). Brown (ibid:128) concludes that to divorce quietly may mean to divorce leniently. Decades later Jesus addresses the to divorce quietly may mean to divorce leniently. Decades later Jesus addresses the concept of divorce (Matt 19:1-12) and specifically the views of Hillel and Shammai, who disputed Deuteronomium 24:1-4. Shammai interpreted the something indecent' portion of Deuteronomium 24 as marital unfaithfulness and Jesus upheld this view. Hillel interpreted the Deuteronomy text to mean that a man may divorce is wife for any infringement of his likes and dislikes - even if she burned the soup Consequently, many Jewish women must have lived in fear and uncertainty, because divorce may have meant a life of hardship, starvation and prostitution. Perhaps remembering his mother's predicament, Jesus opted for Shammai's version, yet added that God's original plan was a lifelong union of one flesh between a man and a woman. Joseph, who became Jesus' legal father, also chooses Shammai's view and decides to divorce Mary because of her perceived marital unfaithfulness.

13.The Announcer invites the audience to imagine a small stone house. Both drama and religion engage the imagination and the dramatic instinct innate in people (see Ehrensperger 1962:100)

14.The story begins. The details of the action, the structure of the dialogue and the various incidents (all causally related) form the plot of a play (DiYanni 2008:920). This is a short play, because 'a good plot will also be economical' (DiYanni ibid:920).

15.Few scholars write on how Joseph learned about Mary's pregnancy. Bailey (2008) and Barclay (1958) are the exceptions. Bailey (ibid:43-47) pauses to consider Joseph's reactions to Mary's pregnancy. Bailey (ibid:43) sees Matthew's editorial comment - 'being a just man' (Matt 1:19) - as meaning that Joseph decided to break the Law of Moses and divorce his betrothed 'quietly rather than exposing her'. Bailey considers this a bold act because it goes beyond the ethical expectations people normally follow when facing their circumstances. Bailey (ibid:44) speculates that Joseph followed the mode of Isaiah's suffering servant (Is $42: 1-6)$, who chooses not to break a bruised reed or quench a dimly burning wick.

16.Von Balthasar (1992:III:293) calls Mary's position 'exceptional'. Her life over the years has entwined emphases on motherhood and the bridal state. Furthermore, she is an 'answering woman' (Von Balthasar ibid:IIl:294) because of her response to Gabriel. For an excellent essay on the development of the analysis and importance of Mary throughout the ages, see Graham Harrison's (Von Balthasar ibid:III-360) translation.

17.The characters in a play may remind us of ourselves or differ from us. They may or may not appeal to us (DiYanni 2008:922). Mary and Joseph are both major characters because the action revolves around them. They are both dynamic 
Joining hands they twirl around centre stage. They obviously want to run to each other's arms, but do not.

Joseph: I am so glad you are back from visiting your relative Elizabeth. ${ }^{18}$ You left so suddenly ${ }^{19}$ and you returned yesterday, is that not right? [Joseph tenderly removes her headdress and/or cowl from her head and lets it fall gracefully on her shoulders.]

Mary: Yes, I did. It was a good trip. ${ }^{20}$ Elizabeth is pregnant and is due any day now. ${ }^{21}$

Joseph: I had heard that! What awesome news! ${ }^{22}$ And at her age $!^{23}$

Mary: [Encouraged. ${ }^{24}$ ] Yes! The Lord is truly moving again in the lives of his people!

Joseph: [His shoulders sag.] Israel has waited so long! We are so oppressed by the Romans! [He makes a spitting noise in disgust. Mary notices. She is calm and gentle. She moves slightly away.] The Messiah truly needs to come! [Mary nods a bit knowingly.]

Joseph: Yes. Well. Tell me about your trip. ${ }^{25}$ Won't you sit down? [He smiles and steps closer to Mary.] I'm sure you told her about our wedding. ${ }^{26}$ It's next month! ${ }^{27}$ [He seats her on one of the benches.]

(Footnote 17 continues ...)

characters, because each grows and changes during the course of the play (DiYann ibid:923). Truly, 'character is the companion of plot', because the actions of the characters propel the plot (DiYanni ibid:924).

18. According to tradition, Elizabeth and Zechariah lived in Ein Karem, about five miles west of Jerusalem and 80 miles from Nazareth (Holy Apostles Convent 1989:119).

19. Hospodar (1956:18) says Mary did not travel to Elizabeth 'in haste' (cum festinatione), but in a serious mood of mind (meta spoudes).

20.Themes common in an account of a super-hero's birth, Brenner (1986:269) writes, are the barrenness of one mother and the unmarried social status of the other. Significantly, there is a lack of rivalry - on issues like status, beauty, ambition, age - between Elizabeth and Mary. Instead, the women are mutually supportive and share the commonality of faith. Brenner (1986:270) points out that the goodwil Mary and Elizabeth enjoy sets the tone for the relationship of their sons by eliminating the possibility of power struggles between them in the future.

21.Mary has thought through what she must tell Joseph. She begins with her stay with her relatives, Elizabeth and Zechariah. This is what we call a subtext (DiYann 2008:928). After telling the good news of Elizabeth's pregnancy first, Mary will eventually tell her own good news to Joseph.

22.Imagination and improvisation are occurring, as Joseph's words and actions show. However, I have kept within the boundaries the biblical text supplied. Joseph is However, I have kept within the boundaries the bibica wo supplied. Joseph is a carpenter and he probably was in his shop working during the day. It is logica to assume that Mary saw him there. For example, Anderson (2006:15) points out that the Bible is not a book of ancient history. Is is more akin to a sixteenth century form of drama that flourished in Italy, the ommedia dell arte. This kind of drama or comedy calls on actors to improvise and to put themselves into the story (Anderson ibid:15). Yes, there were some parts and the director gave an outline of what to do. However, with that said, the actors were 'directed' or told to improvise: they filled in the gaps on their own (see Anderson ibid:15). Therefore, God becomes the Great Dramatist, one who invites a spectator down from the balcony to take part in the drama, with its boundaries, being improvised on stage (see Anderson ibid:15).

23.This play tells its story from the dramatic point of view through the words and actions of the players (Lostracco \& Wilkerson 2008:28). The actors' words and actions interpret their unrevealed thoughts and feelings.

24.I have endeavoured throughout the play to indicate the tone using italics, stage directions, diction, various figures of speech and thought (see Greenblatt 2006:A56-A60).

25.As Mary tells Joseph about her trip and the amazing things that have happened to her, she both speaks for herself and is the subject of the discussion. See Greenblatt (2006:2589-2590) for a fascinating essay on how women defended themselves in prose and verse against written attacks from men - and levelled a few volleys themselves!

26.The betrothal period was probably about a year. The betrothal because of the poverty of Joseph and Mary, probably entailed the simplest of dowries (Holy Apostles Convent 1989:69).

27.There were three steps in a Jewish marriage: the engagement (which might even have occurred when the couple were children), the betrothal and the marriage proper (which occurred at the end of the year of betrothal) (Barclay 1958:9). Significantly, a girl could choose tho become betrothed. However if she did, the betrothal was 'absolutely binding' and people knew the couple as husband and wife during that year although they had no marital rights. Only a divorce could end the betrothal. Here is more on Jewish marriage traditions: The man, the
Mary: $\quad$ Yes. ${ }^{28}$ We did talk a lot about our wedding. Elizabeth and I became quite close, Joseph, probably because wonderful things are happening to both of us. ${ }^{29}$

Joseph: Yes! She's expecting a child-

Mary: [Interrupting.] Yes, a son!

Joseph: [Continuing.]-and at her great age. ${ }^{30}$

Mary: $\quad$ Yes! It's quite a miracle for her and Zechariah! They are known as upright people in the sight of God. $^{31}$

Joseph: [Pausing, considering, and cocking his head.] Ah, Mary, you sound so certain that it is a son. You sound as if you know it is! $!^{32}$

Mary: [Emphatically and confidently.] Well, yes, I do. It's all involved in what I have to tell you. Elizabeth told me I had to talk to you. ${ }^{33}$

Joseph: [Joseph is very pleased that she is here. He obviously enjoys her company and loves her.] Well, tell me about your stay! You left so suddenly and were there about three months, right? ${ }^{34}$

Mary:

[Mary rises.] Yes. You see, Joseph, an angel told Zechariah that he and Elizabeth would have a son. ${ }^{35}$ The meeting took place when Zechariah was serving in the Temple. ${ }^{36}$ Elizabeth and Zechariah

(Footnote 27 continues ...)

betrothed, was the husband, but the woman, the bride, remained in her father's home (France 1989:77). When the betrothal time ended, the man took the bride o his home in a public ceremony. It was then that they could come together and enjoy sexual intercourse (France ibid:77).

28.Throughout this conversation with Joseph, Mary displays an underlying sense of oy an emotion consistent with the material contained in Luke 1 (see Craddock 1990:25-33).

29.One of the main sources of pleasure in a play is surprise (DiYanni 2008:921). In this play, the audience and Mary know more than Joseph knows. Joseph expresses many aspects of surprise throughout the drama.

30.Although Luke 1:6-7 emphasises the couple's outstanding character, it also stresses their outstanding humiliation and outstanding need: they were childless! Childlessness was a valid reason for divorce - and even for excommunication. The rabbis said that seven kinds of people were excommunicated from God. The first two lead the list: 'A Jew who has no wife or a Jew who has a wife and who has two lead' the list: 'A Jew who has no wife or a Jew who has a wife and who has essential social fact about Elizabeth and her great, ongoing disgrace.

31.See Luke 1:5-7. Luke's introduction of Zechariah and Elizabeth as pious, lawbiding saints shows that his narrative emphasises righteous foundations (see Bock 1994:35).

32.The stories of the births of John and Jesus abound with miracles. The Gospel of Matthew presents the situations surrounding Jesus' birth in Bethlehem as filled with intrigue (see Burge, Cohick \& Green 2009:169).

33.Mary was fortunate to have the guidance and confidence of Elizabeth, an older woman. Mary probably sought her counsel about how to tell her betrothed, Joseph, about her situation that definitely affects him: she is a virgin, yet pregnant. Drane (2011:55-57) discusses the difficulties modern readers have with the concept of a virgin birth. 'To be a virgin and pregnant is a contradiction in terms', concept of a virgin birth. 'To be a virgin and pregnant is a contradiction in terms', he (Drane ibid:55) begins and that concept was 'quite unacceptable in any form to orthodox Jews' (Drane ibid:57). Matthew seems to draw from the LXX version of Isaiah, which translates 7:14 as virgin whilst in the Hebrew text the term may refer to a young woman (Drane ibid:56-57). Both Luke and Matthew present the material about Jesus' birth in the same way that they present other material about Jesus: straightforwardly and without elaboration.

34.By this point in the play, we hope that those playing Joseph and Mary have forgotten that they are anybody but Joseph and Mary. Great theatre means that the actors experience a kind of self-forgetting. The actors, performers or preachers become so absorbed in what they are saying that the hows and whys of the performance recede (Childers 1998:96).

35.Angelic visitations that announce births are common throughout the Old Testament (see Gen 16:10-11; 17:15-19; 18:10-15; 25:23; Jdg 13:3-21; Bock 1994:36).

36.Zechariah, who belonged to the priestly order of Abijah, was chosen by lot to minister to the Lord in the temple and burn incense. Whilst going about his duties, an angel of the Lord appeared to him and stood at the right side of the altar of incense (Lk 1:5, 8-9,11). Gundry (2003:217) says that the division of altar of incense (Lk $1: 5,8-9,11)$. Gundry (2003:217) says that the division of
Abijas one of 24 divisions that served in the temple twice a year and for a Abijah was one
week at a time. 
are to name the child John. ${ }^{37}$ [She takes off her shawl/ cowl and neatly folds it. She places it on the corner of the work centre, stage left. It remains there until Joseph picks it up again at the end of the play.]

Joseph: An angel? ${ }^{38}$ [Laughing ${ }^{39}$ and rising.] Our people have not seen angels since Gabriel interpreted a vision for Daniel. ${ }^{40}$ It concerned the end of time. Mmm. Zechariah is quite old, Mary, has he lost his mind? [Joseph walks stage left toward his other work centre.]

Mary: [Laughing and following him.] No! He hasn't lost his mind, but he has lost something else.

Joseph: [Laughing, too.] Really! What?

Mary: [Slowly and looking at Joseph carefully.] He's lost his speech.

Joseph: What? His speech? Why?

Mary: [Quickly.] The angel—and it was Gabriel—told Zechariah that he and Elizabeth would have a son in their old age. ${ }^{41}$ Zechariah did not believe it, and the angel silenced him. ${ }^{42}$

Joseph: Amazing!

Mary: [Laughing] Yes! He's been listening to Elizabeth now for nine months! The angel said he would be silenced until the boy was born.

Joseph: [Still laughing.] Well, good! He used to be so pompous ${ }^{43}$ [He walks stage right toward the other work centre.]

Mary: He has totally changed. I would say he has thought a lot about his encounter with Gabriel. Elizabeth and I would be working around the house and Zechariah would sit at the table, listen to us, and grunt every now and again. Every time he grunted, Elizabeth would hug and kiss him.

Joseph: [Laughing] Well, good! But regarding angels, I'm not so sure! I never have had an encounter with an angel! So I'll suspend judgment about Zechariah's mental competency!

Mary: [Slowly] Mmm. But Joseph, the evidence is there: Elizabeth is pregnant and expecting her child momentarily. Doesn't that verify that Zechariah saw Gabriel?

Joseph: Well, I don't know. It's all pretty far-fetched to me. [Gesturing around the shop.] I deal in realities like hard wood. I know what I make.

37.The child John will become more than a prophet, because he fulfils the prophetic hope of Malachi 4:5-6 that Elijah would return before the day of the Lord' (see Mal 3:1, Lk 7:26 and Matt 17:10-13; also see Burge et al. 2009:200)

38. Repetition, a tool in drama and in the biblical text, invites the audience to pause and consider the meaning and emphasis of the words or phrase (DiYanni 2008:922).

39.Laughter in a conversation between those soon to marry is normal. Von Balthasar (1988:I:436) writes that 'laughter is as much a part of life as weeping: the lighthearted game, the acted or narrated jest, the joke, good humor, poking fun at misconceptions, and inappropriate conduct, the delight we take in the unexpected and unhoped-for that falls into our laps as a gift'.

40.Bock (1994:37) says that the major message of Gabriel's visit to Zechariah and to Luke's readers 'is that God will do what he promises in his own way'.

41.Elizabeth and Zechariah's son, John will, when he grows up, redirect those responding to his message toward a new walk with God (see Bock 1994:37).

42.See Craddock 1990:46.

43.The play notes Mary's affection for Elizabeth and Zechariah. It seems that the miracle of Elizabeth's pregnancy mellowed the elderly priest, because 'Luke introduces Zechariah as something of an old grump' (Branch 2009:35).
Mary: [Mary goes toward him. A work centre separates them.] You do such a good job, Joseph; that's one reason I have grown to love you so much. [Joseph is very pleased. He comes around the work centre to her and takes her hands. Mary looks at him intently.] Joseph, I have something to tell you.

Joseph: [Enjoying holding her hands] Tell me, Mary! But first let me guess! It's about how you'll redecorate my house? [Joseph gestures around his stone house. Mary laughs and shakes her head after each guess].

No? You're going to ask how I like a leg of lamb cooked?

Mary: $\quad$ [Laughing. $\left.{ }^{44}\right]$ You like a lot of spices!

Joseph: [Nodding.] Right. I know! You're going to talk about the wine for our wedding that your father has been saving!

Mary: [Laughing but showing some concern.] No, Joseph, although those are all good guesses! [She pauses and lifts her head to him and draws back a little.] Joseph, what I have to tell you is this: I also saw Gabriel. ${ }^{45}$

Joseph: [Thinking she is joking.] My goodness! It runs in the family! ${ }^{46}$ Does everybody on your side see angels? ${ }^{47}$

Mary: [Seriously but smiling.] No, not everybody, just the ones Gabriel visits.

Joseph: [Dropping her hands and stepping back.] The ones Gabriel visits? [His voice trails off.]

Mary: Yes, Joseph. Gabriel visited me. ${ }^{48}$ [Joseph is amazed. He walks around. Mary gives him time. She's stationary.] He told me things, Joseph, amazing things.

Joseph: [Seriously. Suddenly knowing he's about to hear something extraordinary.] What things, Mary?

Mary: $\quad$ He told me things that made me rejoice. I must say this: 'From now on all generations will call me blessed! The Mighty One has done great things for me and holy is his name! $!^{\prime 49}$ Yes, that is what I have been singing now for three months. ${ }^{50}$

44.Laughter is an important part of theatre. It is an act of reflection and occurs spontaneously. It comments on something or returns something in a tit-for-tat fashion. It may even punish a recognisable human failing (see Bergson 1924:197198). To hit the mark, to make us laugh, it does not necessarily have to be kindhearted (Bergson ibid:198).

45.One tradition is that the annunciation occurred when Joseph was absent from his home and working his trade as a builder (Holy Apostles Convent 1989:71). Another tradition is that Mary lived in the home of Joseph and that he was elderly (Holy Apostles Convent ibid:78).

46. In the theatre, a coincidence that keeps happening becomes a repetition and leads to laughter (see Bergson 1924:90).

47.In Matthew, Joseph receives an angelic announcement. In Luke, Mary receives the angelic announcement (Spivey, Smith \& Black 2010:127).

48. Mary was not looking for God, but the angel Gabriel came to her (Talbert 1985:289).

49.Mary's statements that all generations shall call her blessed and that He who is mighty has done great things for her do not reflect pride or vainglory, because she earlier called herself the handmaid of the Lord (Lk 1:48-49, 38; Holy Apostles Convent 1989:128). Mary links what is happening to her with the history of God's workings with Israel when she sings 'the Mighty One has done great things for me' (O'Day 1985:208). In the gospel of Luke, Mary is a spirit-filled singer (Strauss 2007:265), as this play emphasises. This play does not contain the song of Zechariah, which comes after the circumcision of John and after Mary loaves the home of Zechariah and Elizabeth. It is outside the scope of this play.

50.Deuteronomy 10:21 reflects praise that acknowledges God's goodness, God's actions and brings attention to God (Bock 1994:45). Mary's hymn, or canticle, has similarities with the hymns of praise in the psalms, especially Psalms 33, 47-48, 117 and 135 (Fitzmyer 1981:359). Deuteronomy's 10:21 reflects Luke 1:49: 'he has 
Joseph: Well, Mary, tell me what the angel said.

Mary: [Walking around to give herself time.] He greeted me by saying I had found favour with God. Oh, first of all he told me not to fear. ${ }^{51}$ I guess that was out of courtesy, because he startled me; he arrived so suddenly.

Joseph: [Mystified, running his hand through his hair.] An angel arrived suddenly. Mmm. What were you doing, Mary?

Mary: [With bravado. She is very positive.] Well, nothing much. Just sort of sitting and sewing. ${ }^{52}$ [She goes to a bench, sits, and pantomimes the encounter.] I remember dropping my sewing. ${ }^{53}$ It was then he told me not to be afraid and that I had found favour with God.

Joseph: [With bravado. He is very positive. He speedily comes to her at the bench and kneels. He takes her hand.] Well, of course, you would find favour with God! Everybody knows you are the best young woman in all Nazareth! Everybody respects you. ${ }^{54}$

Mary:

Mmm.

Joseph: [Confident now and in control.] Well, what else did the angel say?

\section{Mary's shocking announcement}

Mary:

[Taking a deep breath and looking at Joseph.] The angel said this: 'You will be with child and give birth to a son and you are to give him the name Jesus.'

Joseph: [Relieved and pleased. Joseph is choosing to believe her. He rises and walks during these lines as he thinks through what Mary has told him.] My goodness, Mary! We will have a son! That's wonderful news! It's interesting that we are to name him Jesus! His name means The Lord Saves! What a famous son he will be. Think of it! Our son.

Mary: Yes, he will be famous, Joseph. [She looks at him intently.]

Joseph: There's more, isn't there, Mary. [She nods. He senses the soberness of the event.] Well, tell me.

(Footnote 50 continues ...)

done great things for me' (Fitzmyer ibid:367). Mary's song does not note the high status of David's royalty 'but the low status of David's humble origins' (Bauckham 2002:73). Mary's social status is consistent with the kind of Messiah she carries. This Messiah comes from 'lowly origins in order to exalt the lowly and to abase the haughty' (Bauckham ibid:74)

51.Conrad (1985:660-663) explores the relationship between fear not and behold. Fear not! is a common command when a heavenly visitor interrupts an earthly scene. Frequently the word Behold! (hinneh) introduces such an encounter in the Old Testament. Behold is a textual marker, a word indicating special emphasis and lerting the hearer or reader that something important is about to be spoke or take place. The Greek equivalent for 'behold' is idou. The angel greets Mary with 'Do not be afraid' (me phobou), Mary'. Behold is omitted. The angel appears to Joseph in a dream also with behold (idou). Conrad (ibid:661) says that 'fea

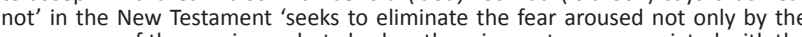
appearance of the numinous, but also by other circumstances associated with the announcement of the birth of a son'.

52.In contrast to the electricity associated with Zechariah's encounter with Gabriel, a simple calmness dominates the angel's visit to Mary (see Bock 1994:39).

53.Commenting on Gabriel's sudden appearance, Gomes (1998:10) quips 'that the angel Gabriel has a lot to answer for, for it is he who interrupts what we might imagine to be the ordinary routine of the life of this young woman about to be married to a carpenter of Nazareth'.

54.This drama does not mention the legends about Mary that include her delayed birth, her holiness, her childhood and her participation with other virgins in making the veil of the Temple. For a fascinating account of them see Holy Apostles Convent 1989:1-73.
Mary: [She begins to walk quickly. She touches her head and then her belly. She seems to be talking to herself. She ends with a prayer with her hands raised and her eyes toward heaven.] Elizabeth said to just tell him straight. Oh, God, be my help $!^{155}$

Mary: Let me continue what the angel said. The angel said that the son I will bear, Jesus, will be great and will be called, [She takes a deep breath.] will be called the Son of the Most High. ${ }^{56}$

Joseph: [Taken aback. Absolutely amazed. He looks around and glances toward the open door. He whispers loudly.] What? Mary! You are speaking blasphemy! Shh! The neighbours might hear!

Mary: [Positively. Honestly. Forthrightly.] No, I am not! I am telling you the truth. I'm telling you what happened. Please believe me, Joseph. [She pauses and slowly continues.] Elizabeth and Zechariah did.

Joseph: [He moves away, stays standing, and folds his arms across his chest.] Continue.

Mary: [Understanding the body language.] The angel kept saying wonderful things about this son, Jesus. He said, 'The Lord God will give him the throne of his father David, and he will reign over the house of Jacob forever; his kingdom will never end.'

Joseph: Well, you and I both are from the house and lineage of David. ${ }^{57}$ My line comes through his son Solomon and yours through Solomon's brother Nathan, also David's son. ${ }^{58}$

Mary: $\quad$ Yes, Solomon and Nathan were the sons of David and Bathsheba.

Joseph: [Musing. Talking to himself. Walking around. He begins to talk things out Slowly.] So if what you say is true, God is on the move and will restore the Kingdom of Israel once again! ${ }^{59}$ Mary, this is

55. What Mary says here, a prayer and a remembrance, is an aside (DiYanni 2008:925). wrote this play with this concept in mind. Mary is living out theology as it develops. So is Joseph. They are human beings whom God is using remarkably. Theology encourages its followers to learn from others. Steuernagel learns from Mary For him (Steuernagel 2003.104), 'The theologian Mary walks around showing off her prenter expectancy of the fulfilment of God's actions. It's theology with the gesture of vocation, pointing towards an obedient discipleship.'

56.Matthew's birth narrative presents the theme that this child, Jesus, is the promised Messiah and will bring salvation to his people (Strauss 2007:224). Matthew 1:1625 highlights the facts that follow. Jesus is born into the household of Joseph, a descendent of David $(1: 16,20)$. Bethlehem is the prophesied birthplace of the upcoming Davidic king (1:23; Mic 5:2). The baby's name, Jesus, Yeshua, means Yahweh Saves $(1: 21)$. The virgin birth confirms the prophetic word in Isaiah that Immanuel, God, will be amongst his people (1:22-23; Is. 7:14) (Strauss ibid:224).

57.Jesus' genealogy in Matthew contains five women - Tamar, Rahab, Ruth, the wife of Uriah the Hittite and Mary - perhaps setting the tone for the 'possibility of the unexpected' in Matthew (Spivey et al. 2010:92). The Christ that Matthew presents 'may not correspond to the image of the Messiah for whom Israel was waiting' (Spivey et al. ibid:92).

58. Matthew 1:1-17 shows the line of Jesus. It starts with Abraham and ends with 'and Jacob the father of Joseph, the husband of Mary, of whom was born Jesus, who is called Christ' (v. 16). Luke 3:23-37 begins: 'Now Jesus himself was about who is called Christ' (v. 16). Luke 3:23-37 begins: 'Now Jesus himself was about thirty years old when he began his ministry. He was the son, so it was thought, of
loseph, the son of Heli' (v. 23). 2 Chronicles 3:1-16 gives the line of David. Verse Joseph, the son of Heli' (v. 23). 2 Chronicles 3:1-16 gives the line of David. Verse
5 is noteworthy for this play: 'And these were the children born to (David) there: 5 is noteworthy for this play: 'And these were the children born to (David) there: Shammua, Shobab, Nathan and Solom. These four were by Bathsheba daughte 2007:414). Matthew's genealogy starts at Abraham and ends with Jesus. Luke's goes in reverse. It links Jesus back to Adam. Here are some differences between the two genealogy accounts (Strauss 2007:414): Luke's list is the longer with 40 names between David and Joseph. Matthew's list contains 26 names. A reason the two differ could be that, whilst both relate to Joseph, Matthew presents the kingly, royal line and Luke gives Joseph's actual forbearers (see Strauss ibid:414).

59.Joseph is correct. God is on the move again in ways and patterns familiar to those who know the history of Israel. Here are some examples: the casting of lots for the determination of Zechariah's time in the temple, a heavenly messenger coming to an old man and later to a maiden, a childless, elderly couple conceiving a son and a delayed child marked as a child of promise (Craddock 1990:26). 
wonderful news! And we are to be the parents of the King! [Joseph muses. His joy is apparent! He walks around shaking his head and lifting his hands in amazement. He is stage right. In jubilation he claps his hands; comes toward Mary. She is centre stage. He grabs her around the waist, twirls her, shoulder to shoulder, once or twice. He releases her. He does a grapevine step toward stage left. His hands are in the air clapping. He twirls by himself once or twice and ends facing the audience. Mary watches, stationary.]

Joseph: Oh, Mary! I believe you! You could not have made me happier! The King of Israel is coming $!^{60}$ God will restore Israel! God will restore Israel through us ${ }^{61}$ [Joseph continues to be very happy. Mary is very silent. Joseph notices. He lowers his hands and turns to her.] Mary, there is more, isn't there?

Mary: $\quad$ Yes. [She turns to Joseph.] Joseph, my betrothed, my darling, I must tell you what more the angel said.

Joseph: [Smiling and very happy.] Continue! I believe you! I am excited!

Mary: Joseph, the angel did not mention you. ${ }^{62}$ [Joseph is startled.]

Joseph: What? I don't understand.

Mary: [She speaks slowly.] I asked how I could have a son since I am a virgin. ${ }^{63}$

Joseph: [Kindly, taking her hands.] Mary, I have no doubt you are a virgin. ${ }^{64}$ I trust you completely. The whole town knows your character. Ah, we will be great parents of the great king!

Mary: $\quad$ Yes. Well, I asked how I could have a son since I am a virgin..$^{65}$ The angel answered that the Holy Spirit will come upon me. ${ }^{66}$

Joseph: What?? [Dropping her hands.] What does that mean? 'The Holy Spirit will come upon' you?

Mary: [Patiently and trying to understand it herself.] Well, it's hard to explain, but it happened. Let me continue telling you what the angel told me. The

60.The child Mary carries is the fulfilment of God's design, because a prophet had spoken generations ago that 'a virgin will conceive and give birth to a son, and they spoken generations ago that 'a virgin will concei
will call him Immanuel' (Burge et al. 2009:169).

61.Respect and awe for God's plan of salvation are factors in Matthew's description of Joseph's characteristic of uprightness or justice (Brown 1979:126)

62.France (1989:76) also notices that there is no mention of Joseph. He expresses it this way: 'That Jesus was conceived by a virgin mother without the agency of Joseph is clearly stated throughout this section' (France ibid:76).

63. Mary's response to the angel, 'How will this be, since I am a virgin?' (Lk 1:34) shows wisdom and prudence, because she wants to know how this is possible (Holy Apostles Convent 1989:101). Howser, Coks (1957.342) sees Mary's question as shos Conention s showing she already had thought about virginity during marriage. He argues, cautiously, that she had prepared herself psychologically for a lifetime of virginity. Globe (1980.54) emphasises the description of Mary as a virgin in both Matthew and Luke. She conceives not by a man, but by the overshadowing of the Holy Spirit. Smith (1975:417) sees Mary's question, 'How can this be?' as our question when we think about Jesus and the promise to humankind that Jesus' story presents.

64.The biblical narrative mentions Mary's virginity twice, once by the narrator and then by Mary herself because of its importance. It is the singular descriptive element about her $($ Lk 1:27, 34). Consequently, this play stresses her virginity. Both Luke and Matthew are more interested in a virginal conception rather than a virginal birth (Spivey et al. 2010:127).

65.Smith (1975:417) sees Mary's question, 'How can this be?' as very much our question, too, when we think about Jesus and the promise to humankind that Jesus' story presents.

66. Mary's account differs markedly from pagan god or man birth stories. Mary's account of what happened to her, better termed a virginal conception than a virgin birth (Strauss 2007:415), emphasises the miraculous. There is no hint of 'a sexual union between Mary and the Holy Spirit' (Strauss ibid:415).
und angel said, 'The Holy Spirit will come upon you, and the power of the Most High will overshadow you. So the holy one to be born will be called the Son of God.'

Joseph: [Puzzled, drawing away.] What? 'The Most High will overshadow you'? 'So the holy one to be born will be called the Son of God. ${ }^{167}$ What do those statements mean?

Mary: I'll tell you. But let me continue what the angel said. Then the angel immediately told me that my relative Elizabeth was going to have a child in her old age and was in her sixth month. It was as if Elizabeth's pregnancy was to be a sign that everything the angel said was true.

Joseph: Well, Elizabeth is pregnant.

Mary: [Taking a deep breath, walking over to him.] Joseph, this is what I must tell you. I am pregnant. ${ }^{68}$

\section{Joseph's anger}

Joseph: [Astounded!] What? ${ }^{69}$ [Many emotions cross his face. Disbelief. Amazement. Anger, especially anger. He backs away from Mary. He storms around the stage. He rubs his hand through his hair. He returns to Mary.] Pregnant? You? Who has done this? ${ }^{70}$ Who has defiled my betrothed? ${ }^{71}$

Mary: $\quad$ No man has defiled me. No one has raped me. I am still a virgin. ${ }^{72}$

Joseph: [Loudly. Beginning to show anger.] But how can you be pregnant? ${ }^{73}$

Mary: [Also loudly.] It was as the angel said. The Holy Spirit came upon me. The power of the Most High overshadowed me. I am pregnant. I am in my third month. I am a virgin..$^{74}$

67. In the Luke account, the phrase 'Son of God', which applies to Mary's child, links to Adam as well (Lk 3:38) (Burge et al. 2009:200).

68.With regard to the angel's visit, Gomes (1998:10) writes that 'it is not an easy thing to be confronted with a message from God'. It is also not an easy thing to say yes to God. Gomes (ibid:10) adds that those who say yes to God, Moses, Abraham, Isaiah, Jeremiah and now Mary, find themselves annoyed 'not so much at their own unworthiness for such a high calling, for that would come later but annoyed own unworthiness for such a high calling, for that would come later but annoyed
at the more practical level of inconvenience'. Mary's pregnancy is, at times, very at the more practical level of inconven
inconvenient, as this play illustrates.

69.The Protoevangelion, which records the interview between Joseph and Mary recounts Joseph's distress, his view that she has been seduced, Mary's tears and his confrontational manner to his betrothed (see Holy Apostles Convent 1989:134135; Protoevangelion: The Lost Books of the Bible 1966).

70.Matthew's account of Jesus' birth shows Joseph's embarrassment at the prospect of the birth of Jesus before he consummates his marriage with Mary (Spivey et al. 2010:90).

71.Evans (2006:217-218) recounts a polemic against Christianity that Celsus wrote in the late second century AD. Amongst other things, Celsus claims that a Roman soldier named Pantera, or Panthera, impregnated Mary. Later rabbinic literature (Tosefta Hullin 2.22-24) also includes this story (Evans ibid:218).

72.Brown's (1979:124) explanation of her virginity, though dated, is still outstanding quote it in full. 'There is never a suggestion in Matthew or in Luke that the Holy Spirit is the male element in a union with Mary, supplying the husband's role in begetting. Not only is the Holy Spirit not male (feminine in Hebrew; neuter in Greek), but also the manner of begetting is implicitly creative rather than sexual.'

73. Bailey (2008:44-46) picks up, as I do, on Joseph's anger, although Bailey calls it Joseph's fuming. He sees the passage, as I do, as showing that Joseph is extremely upset over Mary's condition. It disrupts his life. It shames him. The root of the Greek word for 'he considered' (enthymeomai) (Matt 1:20) is thymos, wrath. Greek word for he considered (enthymeomai) (Matt 1:20) is thymos, wrath. Matthew uses it shortly thereafter to describe the rage of Herod upon discovering where the child lived (Matt 2:16).

74. Here Mary shows her complexity and the complex situation she faces (see Lostracco \& Wilkerson 2008:13). 
Joseph: [Stunned.] That's impossible! ${ }^{75}$ [Slowly.] I, I do not believe you. I cannot believe you.

Mary: $\quad$ I am pregnant. I am a virgin. I am in my third month. ${ }^{76}$

Joseph: [Pleading.] Mary, Mary! We are pledged to be married! In Israel, that is the same as being married! ${ }^{77}$ We have not come together - and I was so looking forward to our wedding night when I could make you my own.

Mary: [Blushing.] Yes, I have dreamed of that, too.

Joseph: [Angry. Laughing in a sneering way.] Yet you are pregnant! You say you are in your third month. You say you are a virgin. A virgin! Ha!78

Mary: [Proudly. Honestly.] No man has known me. I have been faithful to you, my betrothed. ${ }^{79}$ Yes, I am a virgin. Yes, I am pregnant.

Joseph: [Almost screaming.] You lie! What you say is impossible! ${ }^{80}$

Mary: [Also loudly, but honestly and with confidence.] No! And no again! Joseph, Zechariah and Elizabeth believe me. ${ }^{81}$ [Desperately.] Zechariah went to the Isaiah scroll and rolled it out. He pointed to this obscure prophecy from Isaiah and indicated I should share it with you: 'Therefore the Lord himself will give you a sign: The virgin will be with child and will give birth to a son, and will call him Immanuel. ${ }^{82}$

75. A church tradition is that Joseph asks Mary the same question that God earlie asked Eve, 'Why hast thou done this?' (Gen 3:13; Holy Apostles Convent 1989:134asked 135 .

76.Strauss (2007:415) discusses the theological significance of the virginal conception this way: 'Some have argued it was necessary to protect Jesus' sinless nature, but the narratives themselves do not indicate this purpose. The Messiah could have entered human life free from sin with or without a virginal conception. Nor is Scripture explicit on the details of the conception. Did God create the sperm for Mary's egg? Did he create a fertilized embryo? This latter question raises question about how Jesus could have been fully human if he had no physical connection to Mary or Joseph. The former raises the question of how Jesus could have avoided Mary's sinful nature. The Roman Catholic answer is the immaculate conception, whereby Mary herself was born free from sin. However, this doctrine has no basis in Scripture. In the final analysis, the details remain a mystery. What is certain from the text is that the conception of Jesus was a supernytural act of $G$ is confirming the text is that the conception of Jesus was a supernatural act of God, confirmin that God himself was about to accomplish the salvation which no human bein could achieve.' I do not believe that Mary was sinless. This play presents her as a strong, normal young woman. I certainly agree that mystery abounds in the infancy narratives. However, the stories in Luke and Matthew give us enough on which to base our faith. It is a firm foundation. We know enough to trust the Lord. Deuteronomy 29:29 says 'The secret things belong to the Lord our God, but the things revealed belong to us and to our children forever, that we may follow all the words of this law.

77.Brown (1979:127-128) acknowledges that some may be offended that Joseph could regard Mary as an adulteress. However, 'among first-century Christians of Jewish origin this would in no way distract from his upright character'.

78.Joseph immediately assumes she has been unfaithful (Brown 1979:127). Nothing Mary says from here on changes his view. After Joseph decides to divorce Mary Mecause of her here on changes his view. After Joseph decides to divorce Mary bible does not state how lang - a day, a week an evening or an hour. It lasts Bible does not state how long - a day, a week, an evening or an hour. It lasts until an angel of the Lord appears to Jops and wh Mary's units wife, into his home. The angel's statement makes it clear that Mary has not broken the law and become an adulteress (Brown ibid:127). The angel of the Lord puts to rest Joseph's concern that Mary broke the law (Matt 1:20-21).

79.The betrothal meant that people treated the couple as married. However, there had been no consummation. Consequently, matters of inheritance, death, adultery and divorce were handled according to the law. Only a divorce could dissolve the betrothal, as with a marriage (Holy Apostles Convent 1989:69).

80.Othello also does not believe Desdemona's story or her innocence. He calls her foul and claims her chastity is cold (Shakespeare 2008:1094, 272-273).

81.Zechariah and Elizabeth represent the best of Israel. They show that there was true piety, based not on meticulous legalism, but on practiced prayer in Israel (Dean 1983:20).

82.Isaiah 7:14 and Murphy (2005:145) point out that Matthew's choice of virgin shows that he follows the Greek text and not the Hebrew.
Joseph: [Musing.] Immanuel, God with us. ${ }^{83}$ [With derision.] Ha! How can God be with us when he has dashed my dreams? How can God be with us when you have brought shame to my name and to your family's name? Mary! Mary! You know the law!

Mary: Yes, every girl in Israel knows the law from Deuteronomy. Every man, too.

Together: 'If a man is found sleeping with another man's wife, both the man who slept with her and the woman must die. You must purge the evil from Israel. ${ }^{84}$

Joseph: There is more law from Deuteronomy. Mary, were you in town when the man defiled you? You could have cried out and screamed for protection. ${ }^{85}$

Mary: $\quad$ I have not been defiled by a man. I have not been defiled in the city. I did not need to cry out. ${ }^{86}$

Joseph: There is still more law from Deuteronomy. Were you defiled in the countryside? I know you love to walk and pick the wildflowers. Did a man meet you in the countryside in a place far from the town? In a place where no one would hear your cries? ${ }^{87}$

Mary: $\quad$ No. I always go into the countryside with my friends; I am never alone. I was not defiled by a man. I did not need to cry for protection.

Joseph: [He sits.] Because we have been pledged for marriage for more than a year, another law in Deuteronomy cannot apply to you ${ }^{88}$ There is no way for the man who defiled you to pay the 50 shekels to your father and marry you, you, the violated one. ${ }^{89}$

Mary: [She kneels before him and looks up at his face. He turns away.] I have not been violated. I am a virgin. I am pregnant. [Brokenly.] And, and, I love you so very

83.The child Mary carries is the fulfilment of God's design because a prophet had spoken generations ago that 'a virgin will conceive and give birth to a son, and they will call him Immanuel' (Burge et al. 2009:169).

84.See Deuteronomy 22:22.

85.Joseph is trying to find a way out of this pregnancy. He mentions Deuteronomy 22:23-24: 'If a man happens to meet in a town a virgin pledged to be married and he sleeps with her, you shall take both of them to the gate of that town and stone them to death - the girl, because she was in a town and did not scream for help, and the man, because he violated another man's wife. You must purge the evil from among you.' The biblical text hints at what Joseph may be thinking and his dilemma, because it calls him a just man. Concealing an act of fornication or adultery makes one complicit in breaking the law. Joseph did not believe that he ethically could conceal what he determined was her sin of adultery (see Holy Apostles Convent 1989:138).

86.Mary sticks to her story. She keeps affirming the truth of what happened to her Joseph does not believe her. I hope that the audience now begins to see the polarisation of the two sides and to sympathise with both. A critical feature of drama is its mimetic nature: drama is interactive (see DiYanni 2008:900).

87.Joseph brings up Deuteronomy 22:25: 'But if out in the country a man happens to meet a girl pledged to be married and rapes her, only the man who has done this shall die. Do nothing to the girl; she has committed no sin deserving of death. This case is like that of someone who attacks and murders his neighbor, for the man found the girl out in the country, and though the betrothed girl screamed, there was no one to rescue her.'

88.Barclay (1958:9) writes that if Joseph wished to end the betrothal, he could do so in no other way than by divorce; and in that year of betrothal Mary was legally known as his wife'.

89.Joseph also knows this law (see Dt 22:28-29): 'If a man happens to meet a virgin who is not pledged to be married and rapes her and they are discovered, he shall pay the girl's father fifty shekels of silver. He must marry the girl, for he has violated her. He can never divorce her as long as he lives.' The custom was that an engagement consisted of a formal and witnessed agreement to marry and the payment of the consisted of a formal and witnessed agreement to marry and the payment of the
bride price to the father of the bride. The marriage and its celebration and its bride price to the father of the bride. The marriage and its celebr
consummation happened a year later (see Burge et al. 2009:200). 
much, Joseph..$^{90}[$ He does not touch her, but he recoils from her touch and with both hands pushes her away.]

Joseph: [Shouting.] Stoning, Mary, stoning! ${ }^{11}$ [Mary lifts her chin and looks levelly at Joseph. Joseph adopts a pleading attitude.] Mary, the law for a betrothed woman is the same as that for a married woman. Mary, you are deceived! Mary, admit it to me: You broke the Law! You committed adultery!92

Mary: No, Joseph. I cannot lie. ${ }^{93}$ I am a virgin. No man has come near me..$^{94} \mathrm{I}$ am pregnant.

Joseph: [Derision.] And you are pregnant. Who can possibly believe you? Who can possibly believe your, er, story, your explanation?

Mary: [Lifting her chin again. Composed. Smiling while remembering a happy memory.] Elizabeth did without my saying a word..$^{95}$

Joseph: [A derisive grunt.] Elizabeth!

Mary: [Knowing the battle, so to speak, is lost, but still calm, gracious, and loving.] As soon as I arrived, Elizabeth started talking. Actually she started shouting! ${ }^{16}$

Joseph: [Patronisingly.] Well, what did she say?

Mary: [Remembering a good memory, she smiles with fondness.] Elizabeth said to me, 'Blessed are you among women, and blessed is the child you will

90.With this statement, Mary shows that part of the drama in this play involves practical theology. In technical terms, it is action-reflection and theory-praxis (see Stevenson-Moessner 2008.59). Part of the drama, involving the necessity of Mary's

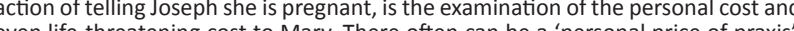
sen praxis', Stevenson-Moes eannete Noel, a woman involved with the Catholic Worker newspaper.

91.Lostracco and Wilkerson (2008:17) note that 'what characters say is often more revealing than their actions; however, in order to draw valid conclusions about a character's personality, the reader must consider the character's words in relation to the character's mood, the situation the character is in, the character's relationship to others in the story, and whether or not the character's behavior is consistent with the words'. Joseph's words and actions clearly show a man distraught, disappointed and very angry.

92. However, Mary has not broken the law, because she conceived through the agency of the Holy Spirit. Therefore, her virginity remains intact (see Brown 1979:127).

93.Throughout the encounter with Joseph, difficult as it is, Mary conducts herself with poise and courage. She does not lie. O'Day (1985:2007) observes that 'Mary speaks of herself in the same way as she speaks of those whom God exalts at the expens of the mighty. God did not choose a woman of wealth and standing to give birth to the savior of Israel, but a woman of low degree, a woman who stands with those who are poor, afflicted and oppressed.'

94. A view that has wide credence in Catholic theology is that Mary preferred virginity even after marriage (Ceroke 1957:329). Ceroke (ibid:329, 342) argues that Joseph later agreed even after their official marriage. Mary may have resisted conjugal relations because of spiritual motives. Ceroke (ibid:334) believes that Mary's response to Gabriel's words was to be greatly troubled (Lk 1:29) and Joseph was perplexed (Matt 1:19-20). Ceroke (ibid:342) concludes that 'there is a natural mystery in many human decisions, and in particular those that 'there is a natural mystery in many human decisions, and in particular those regarding state of life'. It seems to me that the biblical text gives scant support to Ceroke's view. For example, Mark 3:31-35 talks about Jesus' mother and brothers joining a crowd outside a place where he was teaching (see also Matt $12: 46-50$ and Lk 8:19-21). Evidently, in Catholic Church teaching, vowed virginity was 'not a genuine patristic teaching before' Augustine's time and the scholastic later formalised it (Faley 1968:437). If one holds with Mary's perpetual and intentional virginity, one must see it as total dedication to the will of God (Faley ibid:438).

95.Whilst characteristics like blameless and upright describe Zechariah and Elizabeth, the designation virgin describes Mary. Mary becomes the first mode disciple in the new order. Luke 1 shows her as calm, obedient, full of worship, courageous, willing to take God at his word, willing to experience the unknown and willing to believe past her natural understanding. She was even a good songwriter! Likewise, Elizabeth is a model of how to react. Believing and joyful, she is an 'amazed saint' (Bock 1994:43). It seems that Elizabeth's filling by the she is an 'amazed saint (Bock 1994:43). It seems that Elizabeth's filling by the Holy Spirt enabled her to understand Mary's new condition before Mary told her about it. This is significant, because it enabled Elizabeth to believe that Mary this happened.

96.Elizabeth speaks as a prophet (Dean 1983:23). bear! ${ }^{\prime 97}$ Then Elizabeth wondered something very unusual. She said, 'Why am I so favoured, that the mother of my Lord should come to me?'98

Joseph: 'The mother of my Lord'? [Aghast.] Mary, she is calling you the mother of God! ${ }^{9}$

Mary: $\quad$ Yes, I guess she is. ${ }^{100}$ I hadn't really thought of it that way. But yes, that is what she was saying. ${ }^{101} \mathrm{I}$ agree. It is amazing. ${ }^{102}$

Joseph: Mary, everything you say about Elizabeth is against our culture. You are younger! She is the elder! You should be honouring her! ${ }^{103}$ Again, you are deceived, deceived!

Mary: [Sadly, because the man she loves does not understand.] No, I am not deceived. I agree that what I am telling you is hard to understand. Then something funny happened. [Mary's face softens.] Elizabeth started holding her belly. She started laughing! There was lots of activity in her belly! $!^{104}$

Joseph: [Not understanding.] How so?

Mary: $\quad$ Elizabeth told me that as soon as I called out her name, the baby in her womb started leaping for joy! She was filled with the Holy Spirit and started prophesying. ${ }^{105}$

Joseph: [Incredulous.] Prophesying? No woman has prophesied in Israel since Huldah in good king Josiah's time. ${ }^{106}$

97.Fitzmyer (1981:358) notes that Elizabeth gives a blessing and a beatitude over her young kinswoman. Firstly, Mary is blessed (eulogeme) amongst women because
of whom she carries in her womb. Secondly, she is blessed (makaria) because of her faith. With regard to Luke 1:39-45, Dean (1983:23-24) summarises my view nicely: 'Mary was a recipient of grace, not a source of grace. Her blessedness was nicely: 'Mary was a recipient of grace, not a source of grace. Her blessedness was
the blessedness of one who became a willing channel of divine blessings to others.'

98.See Luke 1:42-43. Von Balthasar (1992:III:505-506) sees the biblical text and history as a drama of the living God. He calls history a theodramatic play, because, when seen in a Christian context, God actually appeared in the drama in Jesus Christ, the Son of the Father and the one possessing the Holy Spirit beyond measure.

99.Some view the doctrine that Mary is the Mother of God as the most important truth about Mary. Scripture, tradition, the teaching and authority of the Roman Catholic and Orthodox churches support this (see Holy Apostles Convent 1989:123-124).

100.Luke's account of Mary's visit to Elizabeth distinguishes the roles of the sons the two pregnant women bear. John will be a prophet to the Most High (Lk 1:76) and Mary's son, Jesus, will be the Son of the Most High (Lk 1:32). See Strauss (2007:264-265) for an excellent and succinct explanation of the different roles, (2007:264-265) for an excellent and succinct
functions and ranks of these two baby boys.

101.The concept of theotokos (literally God-bearer) is not to give glory to the mother 'but to guarantee that the life of Jesus was from its inception due to God's act' (Talbert 1985:291). Gomes (1998:15) argues that Mary, in her call from God and in her response to that call, "becomes the mother not only of Jesus but of our vocation, and of our calling as well. She shows us that it is possible for us to be gifted ones with her, the bearers of Christ in our world'.

102.We learn theology on the knife-edge of life. Theology must kneel at the cross, face death, wait for resurrection and adjust to a new season in God's salvific plan. As Steuernagel (2003:110) notes, in his study of Mary, she stood by at the foot of the cross decades later.

103.Actually, Elizabeth correctly honoured Mary, because the son Mary was carrying outranked the son in Elizabeth's womb. The meeting of these four - the two outranked the son in Elizabeth's womb. The meeting of these four - the two
mothers and their two sons - produces 'a new tradition of a super-hero's birth' (Brenner 1986:269).

104.See Luke 1:44. The leaping of the baby John is a prophetic action (Fitzmyer 1981:357). The leaping and the movement of the unborn child in Elizabeth's womb 'is intended as a recognition by him of his relation to Jesus', Fitzmyer (ibid:363) notes. Luke seems to intend a parallel with the matriarch Rebecca. The LXX recounts Genesis 25:22, a similar in-the-womb moment and notes that Rebecca's twins leapt (eskirton) (Fitzmyer ibid:363). The two sons in this part of the story, John and Jesus, meet in their mothers' wombs. They are coming, by God's mercy, into history. Decades later, one proclaims the upcoming salvation and One is that salvation and takes people into that salvation (see Bock 1994:53).

105.See Luke 1:41-45. The Holy Spirit works in families. First Elizabeth was filled and then her husband Zechariah (Lk 1:41,67). Luke makes it clear that the words and views of Elizabeth and, later in the chapter, those of Zechariah 'are not simply views of Elizabeth and, later in the chapter, those of Zechariah are not simply
their own; they sing and prophesy about their son and Jesus in speech inspired by the Holy Spirit' (Craddock 1990:32).

106.See 2 Kings 22 and 2 Chronicles 34:14-28. 
Mary: [Confidently. Straightening her shoulders and lifting her chin.] Yes, indeed. Elizabeth prophesied this about me: 'Blessed is she who has believed what the Lord has said to her will be accomplished!'107

Joseph: It's almost the same as what you said the angel said.

Mary: $\quad$ Yes. The angel greeted me by calling me highly favoured. Their similar words and attitude toward me give me courage to go on.

Joseph: [Suddenly thinking there might be a way out of this dilemma. He loves her and here exhibits a beseeching manner.] Mary. Mary. Maybe you are not pregnant. I'll give you a chance. Young girls don't have regular cycles. Let's agree to this: We'll wait and see. ${ }^{108}$

Mary: Joseph, I cannot agree to that, because I already agreed to something else.

Joseph: [Sternly.] What did you agree to, Mary? You know that I as your betrothed am to be consulted on your vows. ${ }^{109}$

Mary: [Slowly.] Well, when the angel came to me, he told me what I've told you. I was troubled. I was silent. I kept looking up at him and down at my hands. He gave me time to consider a response. [Sighing and laughing.] I felt as if all creation held its breath.

Joseph: [Slowly.] Well, what did you say?

Mary: Looking at Joseph.] I told the angel this: 'I am the Lord's servant. May it be to me as you have said. ${ }^{110}$ Then I curtsied and bowed my head. I don't know why I did that, but I felt as if I were in the presence of royalty. [Laughs quietly and kindly while Joseph looks on and shakes his head.]

Joseph: [Pausing.] Well, what happened next?

Mary: $\quad$ Then the angel left me, and I decided to go quickly to see Elizabeth. ${ }^{111}$ [They look at each other. Joseph paces. It is evident that he is a man with conflicting emotions. Gradually his face hardens. Mary sees it and raises her chin.]

Joseph: Mary, I could have you stoned. [Mary is alarmed, but nods her head.]

107. See Luke 1:45. 'Blessed is she who has believed' gives the essence of a proper response to God: trust that what God says is true and live joyfully in light of that truth (see Bock 1994:44). Landry (1995:78-79) uses an interesting verb, that truth (see Bock 1994:44). Landry (1995:78-79) uses an interesting verb,
congratulates, as he sums up the meeting between the kinswomen. Elizabeth's congratulates, as he sums up the meeting between the kinswomen. Elizabeth's speech 'congratulates Mary for believing that there would be a fulfillment of what
was spoken to her from the Lord'. The scene certainly carries tones of exuberance, was spoken to her from the Lord'. The scene certainly

108.Joseph tries yet another way to work out the conflict that Mary's words brought (see Lostracco \& Wilkerson 2008:21)

109. Here Joseph is citing the laws on vows in Numbers 30:1-9. An unmarried woman's father can overrule her vows if she lives with her father and is under his care (Nm $30: 3-5$ ). The husband of a married woman can release her from rash vows if $h$ nullifies them ( $\mathrm{Nm} \mathrm{30}^{2} 6$-8). The vows of a widow or divorced woman are her own (Nm 30:9). Joseph here rightly asserts that, according to the law, he can nullify Mary's rash vow, because he is her betrothed.

110.Mary's response to Gabriel shows the kind of character that gives the image of the heavenly life (see Holy Apostles Convent 1989:79).

111.Mary shows her faith immediately in three ways: she believes the angel's words, willingly lets God use her and hurries to visit another, Elizabeth, who is also being used amazingly by God (see Bock 1994:44). Scholars wonder about Luke's comment (1:39), Mary set out and went in haste. Fitzmyer (1981:362) opts for eagerness in Mary's departure but advises that this eagerness should not 'be used to analyze Mary's psychology'. The term in haste (meta spoudes), rightly suggests a normal, proper and very human reaction to the angel's good news! The distance could have been as much as 80 miles, might have taken at least four days and perhaps she did it alone (Cooper 2009:95). The text remains silent on these details.
Mary: $\quad$ Oh, Joseph, no. Please believe me! $!^{112}$ How can I convince you that I am telling the truth? ${ }^{113}$ When I told these things to Zechariah and Elizabeth, Zechariah found another passage in the Isaiah scroll.

Joseph: [Petulantly.] Well, what is it?

Mary: [Quietly, confidently.] The Lord is speaking. The Lord says, 'Behold, I will do a new thing. ${ }^{.114}$

\section{Joseph's decision}

Joseph: [Shaking his head and his hand at her.] No!115 There is no 'new thing'! You have committed adultery against me. I dissolve our marriage contract because of your unfaithfulness. That is my verdict. I will have a divorce decree written privately. ${ }^{116}$ You are free to go - [derisively] to go back to your lover! ${ }^{117}$ Leave me. Leave my house! You, the one I loved so much! You have made your father's name an abomination in Israel. ${ }^{118}$

Mary: [Crying.] Oh, Joseph, oh, Joseph, no. You are a just man. ${ }^{19}$

112.Saint Germanos recounts Mary's anguish and her pleading with her betrothed Be penitent, O Joseph! Do not drive me in secret from thy home! I am now in a strange place, and am not accustomed to it. I know neither right from left, and I do not know with whom I might find refuge' (Holy Apostles Convent 1989:136-137; Sermon to the Theotokos, PG 98)

113. Drama seeks to persuade. It is a vehicle for persuasion (DiYanni 2008:899). Mary tries to persuade Joseph that she is telling the truth.

114.See Isaiah 43:19.

115.'The Cherry Tree Carol,' a traditional English carol, notices Joseph's anger and his sharpness toward Mary, both aspects that this drama mirrors. It also emphasises a tradition that Joseph was an old man when he married Mary. However, this play puts the couple at about the same age.

\section{Cherry Tree Carol}

When Joseph was an old man, an old man was he, He married Virgin Mary the Queen of Galilee. He married Virgin Mary the Queen of Galilee.

Joseph and Mary walked out through an orchard wood, There were cherries, there were berries, red as any blood. There were cherries, there were berries, red as any blood.

Then Mary said to Joseph all in a voice so mild:

'Joseph, pick for me some cherries, for I am now with child' 'Joseph, pick for me some cherries, for I am now with child.'

Then Joseph spoke up sharply, and angry words said he. 'Let the father of the baby gather cherries up for thee!' 'Let the father of the baby gather cherries up for thee!'

Then up spoke baby Jesus, He spoke up from the womb, 'Let the tallest tree bend over and give my mother some.' 'Let the tallest tree bend over and give my mother some.'

Then the tallest tree bent over, and into Mary's hand,

And she said, 'Now see here, Joseph, l've cherries by command.'

And she said, 'Now see here, Joseph, I've cherries by command.'

When Joseph was an old man, an old man was he,

He married Virgin Mary the Queen of Galilee.

He married Virgin Mary the Queen of Galilee.

116.A private divorce before two witnesses is possible (Mishnah, Sotah 1:1, 5; France 1989:77). The formal process of divorce is the only way of breaking a betrothal (Babylonian Talmud. m. Ketub. 1:2; 4:2; Hagner 1993:17). A divorce means that the relationship ends. It is a kind of death. Death stands, unuttered, behind every play. Often it becomes its explicit subject matter and not only in tragedy (Von Balthasar 1988:1:369).

117.The Patriarch of Constantinople, Saint Germanos (c. 635-733), in a sermon on the Annunciation, emphasises Joseph's repulsion at Mary's pregnancy and his order that she leave his home immediately and go to the home of her lover (Holy Apostles Convent 1989:136; Sermon to the Theotokos, p. 98).

118. Although Joseph chooses to divorce her - the words of the angel remain true. Mary has found favour with God, she is full of grace and filled with favour from God, 'because she is chosen by the will of God'. God has conferred upon her, despite Joseph's views, 'grace sufficient for her new task' (Gomes 1998:11).

119.Obedience to the law is a key component of Joseph's uprightness (Brown 1979:127). A just man means that Joseph is law-abiding (France 1989:77). A severe legal system demanded that a young woman found not to be a virgin by her husband would be stoned. However a less severe legal system demanded that you 'purge the evil from the midst of you' by divorce (Brown 1979:127). Yet 
Joseph: It is because I am a just man that I cannot marry you. ${ }^{120}$ I cannot say the child is mine. ${ }^{121}[$ Derisively. Brokenly. Defiantly.] The only 'new thing' I will believe is if an angel comes to me, too. ${ }^{122}$ [Mary leaves quickly, obviously broken. ${ }^{123}$ She exists through the open, imaginary door. She freezes with her back to the audience, upstage stage left. Joseph watches her

(Footnote 119 continues ...)

Joseph's action of choosing divorce showed that he was just and merciful (Brown ibid:127).

120.The medieval pageant play, The Annunciation, portrays Joseph as an elderly man who refuses to believe Mary's story (Cawley 1959:74-76). He thinks she has played him the fool. Knowing the child is not his, Joseph says,

'Forsooth, this child, dame, is not mine.

Alas, that ever with mine eyene

I should see this sight!

Tell me, woman, whose is this child?' (lines 114-116)

Accusing her of beguiling him by saying the child is his (as have many other women in similar circumstances), Joseph says,

'But, in faith, Mary, thou art in sin,

So much as I have cherished thee, dame, and all thy kin,

Behind my back to serve me thus.' (lines 130-133)

Joseph then lies down to rest. An angel visits him, commanding him to arise and take Mary home again. He is to comfort her, because she is clean and has conceived the Second Person of the Trinity.

Joseph goes to Mary in haste, kneels before her, and asks her forgiveness. He says,

'Ah, Mary, Mary, I kneel full low;

Forgive me, sweet wife, here in this land.

Mercy, Mary, for now I know

Of your good governance and how it doth stand.' (lines 155-159)

Mary replies,

'Now, that Lord in heaven, sir, he you forgive:

And I do forgive you in his name

For evermore.' (lines 165-166)

Joseph's doubt is a familiar theme in English pageantry and drama. Cawley $(1959: 69)$ notes that themes like Joseph's doubt and Joseph's troubles with Mary occur in English drama cycles.

121.The theme of the play follows. Joseph, because he is a just man, cannot say the child is his. The point of the play (see DiYanni 2008.934) is that he does not believe Mary's story and must have a supernatural confirmation. Bock (2002:64) notes that Mary's story and must have a supernatural confirmation. Bock (2002:64) notes that to Joseph. The shame is contained in Matthew 1:18. However, before they came to Joseph. The shame is contained in Matthew 1:18. However, before they came
together, she was pregnant through the Holy Spirit (italics added). Bock (2002:64) together, she was pregnant through the Holy Spirit (italics added). Bock (2002:64)
continues that, because honour drives the culture, it is virtually required 'that he continues that, because honour drives the culture, it is virtually required 'that he
look for a more faithful potential wife'. The fact that Joseph determines to divorce her quietly tells 'us something of the character of Joseph and are part of the Matthean narrative portrayal of him' (Bock ibid:64). However, I wonder how 'quietly' a divorce could be. Who would marry her? Where would she go? Would her parents take her back into their home? How would she care for the child? Quite likely, Mary wondered these and other things when Joseph told her he would divorce her. The Bible records no angelic visitation to Mary to comfort her, no hugs from Elizabeth and Zechariah who are miles away and no friends to whom Mary could go or in and Zechariah who are miles away and no friends to whom Mary could go or in whom she could confide. The Bible shows another of its consistent silences from God in times of acute distress. However, it seems that the Bible does offer some comfort. God had already spoken to Mary. God had said enough through his trusted representatives, Gabriel and Elizabeth. Mary already had the sure prophetic word. Despite her current circumstances - Joseph's choice not to believe her and his decision to divorce her and the subsequent life-threatening prospects that migh bring - the command and promise of Gabriel hold true: 'Do not be afraid, Mary, fo you have found favour with God' (Lk 1:30). William Blake, the English mystic, poet and artist, held a different view. He interpreted Matthew 1 as showing that Jesus was related to Joseph in spirit and quite possibly in the flesh (Phipps 1971:178). For Blake, if Jesus were indeed Joseph's blood son, 'he could be acclaimed the God-man regardless of his physical mode of generation' (Phipps ibid:178). However, this view seems to me to contradict the statements in Luke 1 and Matthew 1 about the divine nature of Jesus' conception in Mary's womb.

122.This play deliberately portrays Joseph as angry. He expresses his feelings of betrayal and loathing. Mary's declaration seemingly shatters his dreams. Bailey (2008:46) asserts that a better translation of Matthew 1:20 is, 'He considered', 'while he asserts that a better translation of Matthew 1:20 is, 'He considered, 'while he
fumed over this matter' (Bailey's italics). However, a significant attribute of Joseph, a fumed over this matter' (Bailey's italics). However, a significant attribute of Joseph, a just man, is that he is able 'to reprocess his anger into grace,' (Bailey ibid:47). Globe
$(1980: 55)$ also points out that the extraordinary events he has just heard about did (1980:55) also points out that the extraordinary events he has just heard about did
not violate his rights as a Jewish husband. Globe (ibid:55) writes that 'resolving to not violate his rights as a Jewish husband. Globe (ibid:55) writes that 'resolving to
end the betrothal, he is told by an unnamed angel that Mary is not an adulteress
but has conceived by the Holy Spirit, a point the narrator has also made previously but has conceived by the Holy Spirit, a point the narrator has also made previously
$(\mathrm{vv} .18,20)^{\prime}$ '. The angel's words satisfy Joseph and relieve his fears. Joseph sets down rigid terms for believing Mary's story: An angel must tell him it is true. I wrote this mandate as one possible example of what Joseph must have been feeling. Joseph's terms invite the members of the audience to think through their own conditions of belief as well. Theatre succeeds when 'through the special intensity and luminosity of a play of genius, in compelling the spectator to face the concrete dramatic dimensions of his own life', writes Von Balthasar (1988:1:265).

123.The tone of a play or story reveals an author's attitude toward the subject (Lostracco \& Wilkerson 2008:49). The tone of this play throughout has been favourable to Mary. Consider what she faces now. She has the splendid promises of God. She carries the son of God within her. Her betrothed will not protect her name or finances. Her betrothed has told her that he will divorce her. It must really have been a terrible time in her life. go and notices that she has left her shawl. He grabs it, reaches out to the doorway. But she has gone. He holds the shawl against him, buries his face in it, and collapses in tears. He freezes. The Announcer enters.]

\section{Conclusion}

Announcer: Luckily, the story does not end that way. ${ }^{124}$ Yes, Joseph sets his terms, and God meets them. ${ }^{125}$ An angel visits Joseph, too. ${ }^{126}$ Listen as Matthew continues the story. ${ }^{127}$

[Opens the Bible.] Matthew 1:20-25: 'But after he had considered this, an angel of the Lord appeared to him in a dream and said, "Joseph son of David, do not be afraid to take Mary home as your wife, because what is conceived in her is from the Holy Spirit. ${ }^{128}$ She will give birth to a son, and you are to give him the name Jesus, ${ }^{129}$ because he will save his people from their sins."

All this took place to fulfil what the Lord had said through the prophet: 'The virgin will be with child and will give birth to a son, and they will call him Immanuel - which means, "God with us."'

When Joseph woke up, he did what the angel of the Lord had commanded him and took Mary home as his wife. ${ }^{130}$ But he had no union with her until she gave birth to a son. ${ }^{131}$ And he gave him the name Jesus. ${ }^{132}$ [Closes the Bible.]

124.As Bock (2002:64) says, 'Joseph's plans are stopped by a dream. This is one of several such direct interventions in these two chapters (Matt 2:12, 19, 22). God is at work in these events to lead and to guide. Dreams are a consistent and striking feature of the infancy narratives (France 1989:78). Joseph has three of them (Matt feature of the infancy narratives (France 1989:78). Joseph has three of them (Matt $1: 20-21,2: 13$ and 19-21). The magi are warned not to return to Herod (Matt
$1: 12$ ). Because the audience sees and knows more than the characters on the $1: 12$ ). Because the audience sees and knows more than the characters on the
stage do (Ehrensperger 1962:32), what is be happening on the stage may not necessarily be sad.

125.Steuernagel (2003:103) points out that theology begins with unexpected encounters set in the messy confines of day-to-day lives. Joseph's encounter with an angel in a dream changes his theology!

126.The angel's visit in a dream provides Joseph with evidence of Mary's veracity. The visit addresses the concerns he anguished over. 'This afforded him an unquestionable sign and convincing proof that the angel came from God, because it belongs to Him alone to know the secrets of the heart' (Holy Apostles Convent 1989:141).

127.The Announcer is what one calls a static character because he remains the same (Lostracco \& Wilkerson 2008:14)

128.Gundry (2003:170) emphasises the importance of this passage: 'As a result and because of Joseph's descent from David, Jesus is born into a Davidic family and considered legally qualified to inherit David's throne. Joseph's naming Jesus indicates an acceptance of Jesus as his legal son.'

129. Hare (1993:12) writes that 'Joseph's role was simply to acknowledge this part of the miracle by naming the child.

130.Joseph takes Mary into his house (Matt 1:20), thereby establishing the legal Davidic lineage of Jesus (France 1989:77). Hare (1993:11) explains that, for Matthew, Jesus must be recognised as the son of Joseph 'because only so was he an authentic descendant of David'. He (Hare ibid:11-12) adds that 'for Matthew, God's miraculous action in causing the pregnancy included the miraculous God's miraculous action in causing the pregnancy included
incorporation of the child into Joseph's family' (Hare's italics).

131.Citing the verse, 'And Joseph knew her not' (Matt 1:25), Saint Ephraim is amongst those who favour the perpetual virginity of Mary and her abstention from marital relations. Others include Saint Basil, St John Chrysostom and Jerome (see Holy Apostles Convent 1989:148-149). Joseph cared for her all her life and the children associated with his household are his children from an earlier marriage. However, with regard to Matthew 1:24-25, France (1989:80) believes that the Greek phrase not until normally suggests 'that intercourse did not take place until' after Jesus' birth. Therefore, when Matthew later talks about Jesus' brothers (Matt 12:46), they are the children born subsequent to the new family of Joseph and Mary. "There is no biblical warrant for the tradition of the "perpetual virginity" of Mary, France (1989:80) concludes.

132.This birth announcement follows what has become standard procedure in the biblical text. The birth announcement to Joseph, evidently something he needed for him to believe, commends Joseph by addressing him as a descendant (indeed a son!) of David and addressing his fears of taking Mary home with him (Matt 1:20). The angel of the Lord confirms Mary's amazing testimony that her child $1: 20)$. The angel of the Lord confirms Mary's amazing testimony that her child
is from the Holy Spirit. The Matthew account adds these words: He will save his is from the Holy Spirit. The Matthew
people from their sins (Matt 1:21). 
You know, the Bible in this passage gives another summary of a silence. ${ }^{133}$ It does not record the angel's encounter with Joseph in a dream. ${ }^{134}$ It does not record Joseph's conversation with Mary. It does not recount when Joseph tells Mary of his own encounter with an angel. It summarizes all these meetings. But the Bible invites us to imagine them. ${ }^{135}$

[A pantomime begins for Joseph and Mary. ${ }^{136}$ ] From the biblical text we see that Joseph must have believed the angel. ${ }^{137}$ [Joseph raises his head, listens, and indicates agreement.] Joseph must have gone to Mary. [Joseph gets up, runs through the imaginary door, and walks to Mary]. He must have told her of the encounter. [Joseph pantomimes the dream.]

Joseph must have asked for forgiveness. ${ }^{138}$ [Joseph bows or kneels and looks up at Mary.] And Mary must have given her forgiveness. ${ }^{139}$ [Mary indicates her forgiveness; she caresses his bowed head. Joseph rises, relieved. Joining hands, they twirl. Mary smiles. They stop. Joseph bows and offers his arm. ${ }^{140}$ Mary takes it. Together they come through the open door and join the Announcer at centre stage.]

And the story goes on. ${ }^{141}$ [All three bow.]

133.Saint Germanos agrees with the timeframe this play gives. Everything occurred very quickly. Joseph changed his views within a day. The verification he needs comes in a dream from an angel. Joseph immediately repents, goes to Mary and even bows before her (Holy Apostles Convent 1989:142). Saint Germanos, in his homily, acknowledges that Joseph said 'Yesterday I had false suspicions and brought censure upon thy beauty and goodness. But today, having received a word brought censure upon thy beauty and goodness. But today, having received a wor Pless they name! (Holy Apostles Convent 1989:142; Saint Germanos, Patriarch of Constantinople, Sermon on the Annunciation of the Most Holy Theotokos (in Greek), page 98

134.Joseph has four dreams that Matthew recounts. They propel the plot forward and confirm that God is in charge and protecting the child, Joseph and Mary. In addition to Joseph's first encounter with an angel (Matt 1:20-21), Joseph has three more dreams. The first guides him to escape with his family to Egyp (Matt 2:13). The second guides him to return to Israel after Herod's death (2:20). The third guides him to settle in Nazareth (Matt 2:22). An angel also warns the Magi, the wise men from the East, in a dream not to return to Herod (Matt 2:12). Matthew does not name the angel of the Lord. Luke names the angel that visited Zechariah in the Temple and Mary as Gabriel (Lk 1).

135.This play uses imagination within the framework the biblical text supplies. The active imagination of a person (at any age) provides a great tool for training in the faith (see Stonehouse 1998:158).

136. Whilst I was writing this pantomime, I remembered Pitzele's (1998:243-245) three warnings about bibliodrama:

1.At times, a director usurps a priest or rabbi, but a director can be a loose cannon amongst the keepers of the canon.

2. Be aware that bibliodrama may make one too much a slave to the theatre and what may please an audience.

What may please an audience. 3. Bibliodrama may concentrate too much
enough on honouring the biblical text.

In words to himself and to others who love both the theatre and the biblical text, Pitzele (1998:245) wisely points to the value of peer review critics and of sceptical and vocal community.

137.Please note that the angel is unnamed. Perhaps it was Gabriel.

138.Joseph risks scandal by marrying Mary. He does so because he has heard from an angel himself and has decided that he can honourably marry this pregnant woman angel himself and has decided that he can honourably marry this pregnant woman this part of his gospel by affirming Joseph's obedience (Bock 2002:65).

139.Throughout the ages, Mary has been portrayed as gracious. Von Balthasar offers two comments on her importance. Mary's role in the Church can be seen in fruitfulness and as the mother of all believers (see Von Balthasar 1998:V:465). Likewise, Mary serves as the bridge, the transition, between the Old and New Covenants (see Von Balthasar ibid:V:466).

140.The angel's visit confirms that Mary is innocent of sin and, therefore, frees Joseph to marry her (Hagner 1993:18). Joseph's obedience to the angel's directives in marrying Mary and in naming Jesus indicates 'his formal adoption of Jesus and hence the establishment of his Davidic lineage' (Hagner 1993:21).

141.The upcoming marriage of Joseph and Mary takes away any taint of illegitimacy, because an illegitimate child could not enter the assembly of the Lord (Deut 23:2). because an illegitimate child could not enter the assembly of the Lord (Deut 23:2). Significan the scribes and Pharisees, Jesus' laster enemies, never taunted him about being born out of wedlock or that his mother played the harlot in Israel. However, another tradition is that both Mary and Joseph had to drink the waters of conviction (Num 5:11-30) to verify that Mary had not conceived the child she

\section{Acknowledgements Competing interests}

The author declares that she has no financial or personal relationship(s) that may have inappropriately influenced her when she wrote this article.

\section{References}

Anderson, B.W., 2006, The Unfolding Drama of the Bible, Fortress Press, Minneapolis.

Bailey, K.E., 2008, Jesus through Middle Eastern Eyes: Cultural Studies in the Gospels, InterVarsity Press, Downers Grove.

Barclay, W., 1956, The Gospel of Luke, The Westminster Press, Philadelphia.

Barclay, W., 1958, The Gospel of Matthew Volume 1, The Westminster Press, Philadelphia.

Bauckham, R., 2002, Gospel Women: Studies of the Named Women in the Gospels, William B. Eerdmans Publishing Company, Grand Rapids.

Bergson, H., 1924, Laughter: An Essay on the Meaning of the Comic, transl. C. Brereton \& F. Rothwell, MacMillan Company New York.

Bock, D.L., 1994, The IVP New Testament Commentary Series, InterVarsity Press, Downers Grove.

Bock, D.L., 2002, Jesus According to Scripture: Restoring the Portrait from the Gospels, Baker Academic, Grand Rapids.

Branch, R.G., 2009, 'Luke 1:68-79: Exegetical Perspective', in D.L. Bartlett \& B. Brown Taylor (eds.), Feasting on the Word: Preaching the Revised Common Lectionary, Year C, Volume 1: Advent Through Transfiguration, pp. 33, 35, 37, Westminster John Knox, Louisville.

Brenner, A., 1986, 'Female Social Behaviour: Two Descriptive Patterns within the "Birth of the Hero' Paradigm"', Vetus Testamentum 36(3), 257-273. http://dx.doi. org/10.1163/156853386X00320

Brown, D., 2008, God and Mystery in Words: Experience through Metaphor and Drama, Oxford University Press, Oxford. http://dx.doi.org/10.1093/acprof:o so/9780199231836.001.0001

Brown, R.E., 1979, The Birth of the Messiah: A Commentary on the Infancy Narratives in Matthew and Luke, Doubleday, New York.

Burge, M.M., Cohick, L.H. \& Green, G.L., 2009, The New Testament in Antiquity: A survey of the New Testament Within its Cultural Contexts, Zondervan, Grand Rapids.

Cawley, A.C. (ed.), 1959, Everyman and Medieval Miracle Plays, E.P. Dutton \& Co, New York.

Ceroke, C.P., 1957, 'Luke 1:34 and Mary's Virginity', Catholic Biblical Quarterly 19(3) 329-342.

Childers, J., 1998, Performing the Word: Preaching as Theatre, Abingdon Press, Nashville.

Clark, R.E., Brubaker, J. \& Zuck, R.B. (eds.), 1986, Childhood education in the Church, Moody, Chicago.

Conrad, E.W. 1985, 'The Annunciation of Birth and the Birth of the Messiah', Catholic Biblical Quarterly 47(4), 656-663.

Cooper, S.A., 2009, 'Luke 1:39-45 (46-55): Exegetical Perspective', in D.L. Bartlett \& B. Brown Taylor (eds.), Feasting on the Word: Preaching the Revised Common Lectionary, Year C, Volume 1: Advent Through Transfiguration, pp. 93, 95, 97, Westminster John Knox, Louisville.

Craddock, F.B., 1990, Luke, John Knox Press Louisville.

Dean, R.J., 1983, Layman's Bible book Commentary: Luke, Broadman Press, Nashville.

DiYanni, R., 2008, Literature: Approaches to Fiction, Poetry, and Drama, McGraw-Hill, Boston.

Drane, J., 2011, Introducing the New Testament, Fortress Press, Minneapolis.

Edyvean, A.R., 1970, This Dramatic World: Using Contemporary Drama in the Church, Friendship Press, New York.

Ehrensperger, H., 1962, Religious Drama: Ends and Means, Abingdon Press, New York.

Evans, C.A., 2006, Fabricating Jesus: How Modern Scholars Distort the Gospels, IVP Books Downers Grove.

Faley, R.J., 1968, 'Review of J. F. Craghan's Mary, the Virginal Wife and the Married Virgin: The Problematic of Mary's Vow of Virginity (Rome: Gregorian University Press, 1967)', Catholic Biblical Quarterly 30(3), 437-438.

Fitzmyer, J.A., 1981, The Gospel According to Luke I-IX: Introduction, Translation, and Notes, Doubleday, New York.

(Footnote 141 continues ...)

carried in adultery or out of wedlock. Both took the waters, both went separately into the hill country for the appointed time and both returned! The priest who administered the test said, 'If the Lord God did not make manifest your sin, neither will I judge you' (see Holy Apostles Convent 1989:145-147). To experience neither will I judge you' (see Holy Apostles Convent 1989:145-147). To experience
a play - its writing, rehearsals, performances and reception - can engage the a play - its writing, rehearsals, performances and reception - can
imagination, the will and the direction of a life (see Forde 1990:4). 
Forde, N., 1990, Theatercraft: Creativity \& the Art of Drama, Harold Shaw, Publishers, Wheaton.

France, R.T., 1989, Tyndale New Testament Commentaries: Matthew, William B. Eerdmans, Grand Rapids.

Globe, A., 1980, 'Some Doctrinal Variants in Matthew 1 and Luke 2, and the Authority of the Neutral Text', Catholic Biblical Quarterly 42 (1), 52-72.

Gomes, P.J., 1998, Sermons: biblical Wisdom for Daily Living, William Morrow and Company, Inc, New York.

Greenblatt, S., 2006, The Norton Anthology of English Literature, W. W. Norton \& Company, New York.

Gundry, R.H., 2003, A Survey of the New Testament, 4th edn., Zondervan, Grand Rapids.

Hagner, D.A., 1993, Word Biblical Commentary, Volume 33A: Matthew 1-13, Word Books, Publisher, Dallas.

Hare, D.R.A., 1993, Matthew, John Knox Press, Louisville.

Holy Apostles Convent, 1989, The Life of the Virgin Mary, the Theotokos, Holy Apostles Convent, Buena Vista, Colorado.

Hospodar, B., 1956, 'Meta spoudes in Luke 1:39', Catholic Biblical Quarterly 18(1), 14-18.

Landry, D.T., 1995, 'Narrative Logic in the Annunciation to Mary (Luke 1:26-38)' Journal of Biblical Literature 114(1), 65-79. http://dx.doi.org/10.2307/3266590

Long, T.G., 2001, Beyond the Worship Wars: Building Vital and Faithful Worship, The Alban Institute, NP.

Lostracco, J. \& Wilkerson, G., 2008, Analyzing Short Stories, Kendall/Hunt Publishing Company, Dubuque.

Murphy, F.J., 2005, An Introduction to Jesus and the Gospels, Abingdon Press, Nashville.

O'Day, G.R., 1985, 'Singing Woman's Song: A Hermeneutic of Liberation', Currents in Theology and Mission 12(4), 203-210.

Protoevangelion, 1966, The Lost Books of the Bible, Meridian Books, New York.
Quash, B., 2005, Theology and the drama of history, Cambridge University Press, Cambridge.

Phipps, W.E., 1971, 'Blake on Joseph's Dilemma', Theology Today 28(2), 170-178. http://dx.doi.org/10.1177/004057367102800204

Pitzele, P.A., 1998, Scripture Windows: Towards a Practice of Bibliodrama, ALEF Design Group, Los Angeles.

Shakespeare, W., 2008, 'The Tragedy of Othello', Volume IV, Scene III, in R. DiYanni, (ed.), Literature: Approaches to Fiction, Poetry, and Drama, pp. 1012-1097, McGraw-Hill, Boston.

Smith, D.M., 1975, 'Exposition of Luke 1:26-38', Interpretation 29(4), 411-417. http:// dx.doi.org/10.1177/002096437502900406

Spivey, R.A., Smith, D.M. \& Black, C.C., 2010, Anatomy of the New Testament, 6th edn., Fortress Press, Minneapolis.

Steuernagel, V.R., 2003, 'Doing Theology with an Eye on Mary', Evangelical Review of Theology 27(2), 100-112.

Stevenson-Moessner, J., 2008, Prelude to Practical Theology, Abingdon Press, Nashville.

Stonehouse, C., 1998, Joining children on the spiritual journey: nurturing a life of faith, Baker, Grand Rapids.

Strauss, M.L., 2007, Four Portraits, One Jesus: An Introduction to Jesus and the Gospels, Zondervan, Grand Rapids.

Talbert, C.H., 1985, 'Luke 1:26-31', Interpretation 39(3), 288-291. http://dx.doi. org/10.1177/002096438503900306

Von Balthasar, H.U., 1988, Theo-Drama: Theological Dramatic Theory, Volume 1: Prolegomena, transl. G. Harrison, Ignatius Press, San Francisco.

Von Balthasar, H.U., 1992, Theo-Drama: Theological Dramatic Theory, Volume III: The Dramatis Personae: The Person in Christ, transl. G. Harrison, Ignatius Press, San Francisco.

Von Balthasar, H.U., 1998, Theo-Drama: Theological Dramatic Theory, Volume V: The Last Act, transl. G. Harrison, Ignatius Press, San Francisco.

Wells, S., 2004, Improvisation: The Drama of Christian Ethics, Brazos Press, Grand Rapids. 